\title{
Merkel Cell Carcinoma Clinical Distant Metastasis TNM Finding v8
}

National Cancer Institute

\section{Source}

National Cancer Institute. Merkel Cell Carcinoma Clinical Distant Metastasis TNM Finding v8. NCI Thesaurus. Code C136834.

A clinical finding about one or more characteristics of Merkel cell carcinoma, following the rules of the TNM AJCC V8 classification system as they pertain to distant metastases. 